\title{
Pelaksanaan Pembelajaran Pendidikan Agama Islam dalam Menanamkan Nilai-Nilai Kejujuran
}

\author{
Viviana Fahira ${ }^{1}$, Rengga Satria ${ }^{2}$, Ageng Priadi $^{3}$ \\ vivianafahira2019@gmail.com1, renggasatria@fis.unp.ac.id², agengpriadi87@gmail.com³ \\ Universitas Negri Padang ${ }^{1,2}$, SMKN 1 Karimun $^{3}$
}

\begin{tabular}{l}
\hline ARTICLE INFO \\
\hline Article history: \\
Received, 21 October 2021 \\
Revised, 11 November \\
2021 \\
Accepted, 30 November \\
2021 \\
\hline Keywords: \\
Pelaksanaan, Pembelajaran \\
PAI, Nilai-Nilai Kejujuran \\
\\
\hline Clonflict of Interest: \\
None
\end{tabular}

Funding:

None

\begin{abstract}
Tujuan penelitian ini adalah untuk mengetahui bagaimana pelaksanaan pembelajaran PAI dalam menanamkan nilai-nilai Kejujuran siswa di SMPN 2 Kota Solok, peran pendidikan Islam sangat dibutuhkan dalam menanamkan nilai-nilai kejujuran, dimana menjadi era yang penuh tantangan dihadapi oleh para siswa saat ini, para siswa menjadi bingung dan bertanya-tanya mereka harus melakukan apa dan bagimana harus bersikap. Melalui Pendidikan Agama Islam siswa-siswa dapat memiliki bekal untuk memiliki karakter jujur dalam kehidupan sehari-hari. Jenis penelitian ini menggunakan pendekatan kualitatif yang bersifat deskriptif, sumber data dalam penelitian ini meliputi sumber data premier dan sumber data sekunder, metode yang digunakan dalam penelitian ini adalah observasi, wawancara, dan dokumentasi. Analisis dalam penelitian menggunakan analisis data dari Sugiono. Penganalisisan data dengan reduksi data, penyajian data, dan penarikan kesimpulan. Untuk pengabsahan data peneliti menggunakan triangulasi dari sumber yang berbeda. Hasil dari penelitian ini bahwa guru PAI mempunyai peran yang penting untuk menanamkan nilai-nilai kejujuran pada peserta didik dalam proses pembelajaran.
\end{abstract}

Corresponding Author: Viviana Fahira, Departemen Islamic Education Faculty of Social Science Universitas Negeri Padang, Indonesia, Email: vivianafahira2019@gmail.com, Phone: $+6282111880701$

\footnotetext{
\begin{tabular}{l|c|l|l}
\hline & (C) $\stackrel{()}{\mathrm{EY}}$ & Copyright $(2021$, Author(s) \\
\hline
\end{tabular}

1. Pendahuluan

Pendidikan ialah suatu upaya yang disusun secara terencana untuk membimbing dan melakukan pembelajaran bagi suatu individu agar individu tersebut berkembang dan tumbuh menjadi manusia yang mandiri, bertanggungjawab, kreatif, berilmu, sehat, dan berakhlak mulia baik dilihat dari aspek jasmani maupun rohani (Indah, 2012: 110).

Pendidikan berfungsi mengembangkan kemampuan dan membentuk watak serta peradaban bangsa yang bermartabat dalam rangka mencerdaskan kehidupan bangsa, bertujuan untuk berkembangnya potensi peserta didik agar menjadi manusia yang beriman dan bertakwa kepada Tuhan Yang Maha Esa, berakhlak mulia, sehat, berilmu, cakap, kreatif, dan menjadi warga negara yang demokratis dan bertanggung jawab. (Amin, 2017: 105-124)
} 
Menurut Kun Setyaning Astuti yang dikutip oleh Darmiyati Zuchdi bahwa "terdapat 16 nilai-nilai dasar target pendidikan karakter, yaitu ; taat beribadah, jujur, bertanggung jawab, disiplin, memiliki etos kerja, mandiri, sinergis, kritis, kreatif dan inovatif, visioner, kasih sayang dan peduli, ikhlas, adil, sederhana, nasionalisme dan internasionalisme" (Darmiyati Zuchdi, 2011: ) .

Atas dasar pengertian di atas, maka dapat dipahami bahwa salah satu inti dari pendidikan karakter adalah penanaman nilai kejujuran. "Jujur" Menurut Agus Wibowo, "jujur diartikan sebagai perilaku yang didasarkan pada upaya menjadikan dirinya sebagai orang yang selalu dapat dipercaya dalam perkataan, tindakan dan pekerjaan". (Agus Wibowo, 2012: 149)

Sejalan dengan hal itu, Nurul Zuriah menyatakan bahwa "jujur merupakan sikap dan perilaku yang tidak suka berbohong dan berbuat curang, berkata apa adanya, dan berani mengakui kesalahan. Jujur bisa diartikan mengakui, berkata atau memberikan informasi sesuai dengan kenyataan yang sebenarnya". ( Nurul Zuriah, 2007: 83)

Atas dasar pengertian diatas dapat disimpulkan kejujuran adalah sebuah kata yang tidak asing lagi bagi kita dan sangatlah mudah untuk diucapkan, terutama di dunia pendidikan, para guru dalam setiap pembelajaran selalu menekankan kejujuran kepada siswanya. Kondisi ini mencerminkan bahwa kejujuran adalah sesuatu yang penting dan sangat berharga. Kondisi ini mencerminkan bahwa kejujuran adalah sesuatu yang penting dan sangat berharga.

Pembentukan sikap kejujuran di sekolah dapat ditunjukkan dengan beberapa indikator yaitu (1) tidak meniru jawaban teman (mencontek), (2) mengatakan dengan sejujurnya tentang sesuatu yang barusaja dialaminya. (3) mau bercerita tentang kesulitan dan mau menerima pendapat teman (4) mau menyatakan tentang ketidaknyamanan suasana didalam kelas, (5) menjawab pertanyaan guru berdasarkan yang diketahuinya. ( Shafwat Abdul Fattah, 2010)

Peran pendidikan Islam sangat dibutuhkan dalam menanamkan nilai-nilai kejujuran, dimana menjadi era yang penuh tantangan dihadapi oleh para siswa saat ini, para siswa menjadi bingung dan bertanya-tanya mereka harus melakukan apa dan baimana harus bersikap. Melalui Pendidikan Agama Islam siswa-siswa dapat memiliki bekal untuk memiliki karakter jujur dalam kehidupan sehari-hari. (Ningsih, 2019).

Peran Pendidikan Agama Islam sama dengan peran Pendidikan kepribadian atau Akhlak adalah membentuk manusia berakhlak mulia, yaitu suatu keadaan yang melihat pada diri manusia tanpa melalui proses perhitungan, pemikiran dan penelitian yang menimbulkan hal yang baik yang disebut karakter jujur. (Sada, 2015: 205)

Atas dasar pengertian diatas begitu pentingnya penerapan sebuah kejujuran pada diri siswamelaluiprosespembelajaran Pendidikan Agama Islam di kelas 7 SMPN2 Kota Solok, yaituuntukmelatih kebiasaan sejak dini agar kedepannya menjadi lulusan yangtidakhanya berkompetendalampengetahuansematamelainkan jugamemiliki kepribadianyang jujur.

Berdasarkan wawancara peneliti dengan salah satu guru PAI yang bernama Gustiwarni dan guru BK yang bernama Dilla Fakhma Yuni pada tanggal 20 oktober 2020 mengungkapkan bahwa sekitar $70 \%$ siswa kelas 7 masih berprilaku tidak jujur. Contohnya yaitu masih seringnya siswa mencontek ketika ulangan, masih banyaknya siswa yang mengerjakan pekerjaan rumah di sekolah, masih banyaknya siswa yang berbagi jawaban saat ujian, serta masih banyak siswa yang curang saat belanja dikantin sehingga kantin mengalami kerugian.

Ibu Hj. Gustiwarni juga mengungkapkan bahwasanya pada mata pelajaran Pendidikan Agama Islam kelas 7 dalam KD 2.5 - KD 4.5 siswa mempelajari materi tentang kejujuran, dengan adanya materi tersebut harapannya siswa yang awalnya belum bisa bersikap jujur, bisa mengaplikasikan sikap jujur yang telah dipahami setelah melakukan pembelajaran PAI. 
Viviana Fahira, Rengga Satria, dan Ageng Priadi: Pelaksanaan Pembelajaran Pendidikan Agama...

\section{Tinjauan Pustaka}

\section{Kejujuran}

\section{a. Pengertian Kejujuran}

Jujur didalam Al Quran diungkapkan dengan kata shidiq. Artinya adalah memberitahukan, menuturkan sesuatu dengan sebenarnya, sesuai dengan fakta kejadiannya. (Samsul dan Amin, 2016: 205).

Menurut Agus Wibowo, "jujur diartikan sebagai perilaku yang didasarkan pada upaya menjadikan dirinya sebagai orang yang selalu dapat dipercaya dalam perkataan, tindakan dan pekerjaan" (Agus Wibowo, 2012: 14). Sejalan dengan hal itu, Nurul Zuriah menyatakan bahwa "jujur merupakan sikap dan perilaku yang tidak suka berbohong dan berbuat curang, berkata apa adanya, dan berani mengakui kesalahan (Nurul Zuriah, 2007: 83).

Soemantri mengatakan bahwa "nilai merupakan hal yang terkandung dalam hati nurani manusia yang lebih memberi dasar dan prinsip akhlak yang merupakan standar dari keindahan dan efisiensi atau keutuhan kata hati (potensi)" (Fandi Setiawan, 2013: 75).

Atas dasar pengertian diatas dapat disimpulkan bahwasanya Jujur adalah menyatakan apa adanya, konsisten antara apa yang dikatakan dan dilakukan, serta berkata atau memberikan informasi sesuai dengan kenyataan yang sebenarnya.

\section{b. Pembagian sifat jujur}

Menurut Amin (2017) Imam Al Ghazali membagi sifat jujur atau shiddiq dalam lima hal yaitu:

1) Jujur dalam perkataan

Jujur dalam perkataan mengandung makna bahwa tiap kata yang keluar dari mulut seseorang hendaklah memuat atau mengandung nilai-nilai kebenaran dan penuh kejujuran. Setiap informasi yang diterima memiliki kesesuaian dengan informasi yang disampaikan, setiap perkataannya tidak lain adalah kebenaran, sehingga ia akan selalu menjaga lidahnya dengan menyampaikan berita yang sesuai dengan fakta, bukan gunjingan, gosip atau fitnah.

2) Jujur dalam niat

Jujur dalam niat, artinya tidak ada tindakan yang dilakukan bagi seseorang selain karena dorongan dari Allah SWT semata-mata. Niat seorang haruslah diiringi dengan kemauan dan kejujuran, bahwa dirinya akan berupaya sekuat tenaga untuk mewujudkan niatnya tersebut.

3) Jujur dalam kemauan

Jujur dalam kemauan, adalah usaha agar terhindar dari kesalahan-kesalahan dalam menyampaikan kebenaran. Ia akan berpikir masak-masak, menimbangnimbang baik buruknya terlebih dahulu sebelum melakukan tindakan. Setiap tindakan yang ingin dicapai tiada lain adalah hal-hal yang dibenarkan oleh agama.

4) Jujur dalam menepati janji

Janji adalah hutang, karena janji merupakan hutang, maka ia harus dan wajib dibayar sesuai nilai dari hutang tersebut. Jika seseorang berjanji, berarti ia memberikan keyakinan kepada oranglain bahwa ia akan sanggup menepatinya. Dengan memiliki sikap jujur, maka orang yang berjanji akan mampu menunaikan janjinya, karena ia sadar betul bahwa setiap janji wajib ditepati, sebagaimana halnya hutang, wajib dibayar.

5) Jujur dalam perbuatan

Jujur dalam perbuatan merupakan realisasi dari setiap unsur kejujuran, karena melalui perbuatan akan dapat diketahui kejujurannya. Jujur dalam perbuatan, maksudnya memperlihatkan sesuatu itu apa adanya, tidak dibuat-buat dan basa-basi, aktivitas lahiriyah sesuai dengan batinnya.

Dari 5 pembagian sifat jujur diatas, peneliti hanya meneliti bagaimana pelaksanaan pembelajaran PAI dalam menanamkan nilai-nilai kejujuran dari segi 
perbuatan(amaliah), karna berdasarkan wawancara dengan guru BK dan guru PAI, siswa kelas 7 banyak yang tidak jujur dari segi perbuatannya yaitu masih banyak siswa yang mengerjakan tugas di sekolah, masih banyaknya siswa yang mencontek ketika ulangan serta masih banyak siswa yang tidak jujur dalam berbelanja di kantin.

\section{Pelaksanaan pembelajaran PAI}

\section{a. Pengertian pembelajaran Pendidikan Agama Islam}

Menurut Oemar Hamalik mendefinisikan pembelajaran sebagai suatu kombinasi yang tersusun, meliputi unsur-unsur manusiawi, fasilitas, perlengkapan dan prosedur yang saling mempengaruhi untuk mencapai tujuan pembelajaran (Oemar Hamalik, 2007: 57)

Pada hakekatnya pembelajaran terkait dengan bagaimana membelajarkan peserta didik atau bagaimana membuat peserta didik dapat belajar dengan mudah dan terdorong oleh kemampuannya sendiri untuk mempelajari apa yang teraktualisasikan dalam kurikulum sebagai kebutuhan peserta didik (Muhaimin, 2008: 145)

Zuhairimi mengartikan Pendidikan Agama Islam sebagai asuhan-asuhan secara sistematis dalam membentuk anak didik supaya mereka hidup sesuai dengan ajaran Islam (Zuhairimi, 2007: 25) Sedangkan Zakiyah Drajat dalam bukunya ilmu pengetahuan Pendidikan Agama Islam menyatakan bahwa Pendidikan Agama Islam adalah usaha berupa bimbingan dan asuhan terhadap anak didik agar kelak setelah selesai pendidikannya dapat memahami dan mengamalkan ajaran agama serta menjadikannya sebagai pedoman sebagai pandangan hidup (Rofiq, 2010: 1-14).

Atas dasar pengertian diatas dapat disimpulkan pembelajaran Pendidikan Agama Islam dapat diartikan sebagai upaya membuat peserta didik dapat belajar, terdorong belajar, mau belajar dan tertarik untuk terus menerus mempelajari Agama Islam secara menyeluruh yang mengakibatkan beberapa perubahan dalam dirinya.

\section{b. Fungsi Pembelajaran Pendidikan Agama Islam di Sekolah}

Pelaksanaan pembelajaran Pendidikan Agama Islam di sekolah tidak terlepas dari fungsi pendidikan agama Islam sebagai proses transformasi ilmu dan pengalaman. Abdul Majid mengemukakan tujuh fungsi pendidikan Agama Islam di sekolah atau madrasah, di antaranya:

1. Pengembangan, yaitu meningkatkan keimanan dan ketakwaan peserta didik kepada Allah SWT yang telah ditanamkan dalam lingkungan keluarga. Pada dasarnya dan pertama-tama kewajiban menanamkan keimanan dan ketakwaan dilakukan oleh setiap orang tua dalam keluarga. Sekolah berfungsi untuk menumbuhkembangkan lebih lanjut dalam diri anak melalui bimbingan, pengajaran, dan pelatihan agar keimanan dan ketakwaan tersebut dapat berkembang secara optimal sesuai dengan tingkat perkembangannya.

2. Penanaman nilai, sebagai pedoman hidup untuk mencari kebahagiaanhidup di dunia dan akhirat.

3. Penyesuaian mental, yaitu untuk menyesuaikan diri dengan lingkungannya baik lingkungan fisik maupun lingkungan sosial dan dapat mengubah lingkungannya sesuai dengan ajaran Agama Islam.

4. Perbaikan, yaitu untuk memperbaiki kesalahan-kesalahan, kekurangankekurangan, dan kelemahan-kelemahan peserta didik dalam keyakinan, pemahaman dan pengalaman ajaran dalam kehidupan sehari-hari.

5. Pencegahan, yaitu untuk menangkal hal-hal negatif dari lingkungannya atau dari budaya lain yang dapat membahayakan dirinya dan menghambat perkembangannya menuju manusia Indonesia seutuhnya.

6. Pengajaran, tentang ilmu pengetahuan keagamaan secara umum, sistem dan fungsionalnya.

7. Penyaluran, yaitu untuk menyalurkan anak-anak yang memiliki bakat khusus di bidang Agama Islam agar bakat tersebut dapat berkembang secara optimal 
Viviana Fahira, Rengga Satria, dan Ageng Priadi: Pelaksanaan Pembelajaran Pendidikan Agama...

sehingga dapat dimanfaatkan untuk dirinya sendiri dan bagi orang lain (Majid, 2010: 15-16)

Ketujuh fungsi pendidikan agama Islam yang dikemukakan oleh Abdul Majid menggambarkan bahwa peran Pendidikan Agama Islam di Sekolah sangat penting guna membentuk karakter peserta didik untuk menjadi pribadi muslim yang sempurna lewat pengajaran dan kegiatan yang diadakan di sekolah.

\section{c. Fungsi dan Peranan Pembelajaran Pendidikaan AgamaIslam di SMP}

Ajaran agama merupakan pedoman bagi kehidupan manusia, baik di dunia maupun kelak di akhirat. Untuk itu fungsi dan peranan Pendidikan Agama Islam dalam kehidupan sehari-hari dapat dikemukakan sebagai berikut:

1. Agama akan memberikan makanan rohani

2. Rohani merupakan ruh atau jiwa seseorang yang mempunyai pengaruh terhadap pikirannya. Agama Islam merupakan sebagai makanan dan siraman sejuk untuk mengisi hatinya agar selalu dekat dengan Tuhan penciptanya.

3. Agama akan menanggulangi kegelisahan hidup

4. Beban masalah membuat manusia mengalami kegelisahan dalam hidupnya. Dengan ber-agama dan memahami ajaran Islam, agama akan memberi ketenangan jiwa dan berusaha mencari solusi terbaiknya serta bertawakal kepada Allah swt.

5. Agama memenuhi tuntutan fitrah

Fitrah merupakan naluri manusia yang telah ada sejak ia lahir. Manusia akan selalu mencari Tuhan sebagai sang penciptanya. Oleh sebab itu, manusia wajib mempunyai agama sebagai sifat atau fitrah manusia yang membedakannya dengan makhluk lain(hewan).

\section{d. Tahap yang dilakukan guru dalam pembelajaran}

Sukmadinata yang dikutip oleh E. Mulyasa mengemukakan tiga tahap yang dilakukan guru dalam proses pembelajaran, yakni perencanaan, pelaksanaan, dan evaluasi pembelajaran (E. Mulyasa, 2012: 98)

1) Perencanaan

Perencanaan adalah menyusun langkah-langkah yang akan dilaksanakan untuk mencapai tujuan yang telah ditentukan (Abdul Majid, 2012:15), menurut Tjokroamidjojo (Syafalevi,2011: 27) perencanaan dalam arti seluas-luasnya merupakan suatu proses mempersiapkan secara sistematis kegiatan-kegiatan yang akan dilakukan untuk mencapai suatu tujuan tertentu. Dengan demikian perencanaan merupakan sebuah skenario pembelajaran yang akan dilaksanakan oleh guru sebelum mengajar.

Menurut Permendikbud Nomor 22 Tahun 2016 Rencana Pelaksanaan Pembelajaran (RPP) adalah rencana kegiatan pembelajaran tatap muka untuk satu pertemuan atau lebih. RPP dikembangkan dari silabus untuk mengarahkan kegiatan pembelajaran peserta didik dalam upaya mencapai Kompetensi Dasar (KD).

Setiap pendidik pada satuan pendidikan berkewajiban menyusun RPP secara lengkap dan sistematis agar pembelajaran berlangsung secara interaktif, inspiratif, menyenangkan, menantang, efisien, memotivasi peserta didik untuk berpartisipasiaktif, serta memberikan ruang yang cukup bagi prakarsa, kreativitas, dan kemandirian sesuai dengan bakat, minat, dan perkembangan fisik serta psikologis peserta didik. RPP disusun berdasarkan KD atau subtema yang dilaksanakan kali pertemuan atau lebih (Permendikbud, 22: 2018)

Komponen RPP terdiri atas:

a. identitas sekolah yaitu nama satuan pendidikan

b. identitas mata pelajaran atau tema/subtema

c. Kelas/semester;

d. materi pokok 
e. alokasi waktu ditentukan sesuai dengan keperluan untuk pencapaian KD dan beban belajar dengan mempertimbangkan jumlah jam pelajaran yang tersedia dalam silabus dan KD yang harus dicapai

f. tujuan pembelajaran yang dirumuskan berdasarkan KD, dengan menggunakan kata kerja operasional yang dapat diamati dan diukur, yang mencakup sikap, pengetahuan, dan keterampilan

g. kompetensi dasar dan indikator pencapaian kompetensi

h. materi pembelajaran, memuat fakta, konsep, prinsip, dan prosedur yang relevan, dan ditulis dalam bentuk butir-butir sesuai dengan rumusan indikator ketercapaian kompetensi

i. metode pembelajaran, digunakan oleh pendidik untuk mewujudkan suasana belajar dan proses pembelajaran agar peserta didik mencapai KD yang disesuaikan dengan karakteristik peserta didik dan KD yang akan dicapai

j. media pembelajaran, berupa alat bantu proses pembelajaran untuk menyampaikan materi pelajaran

k. sumber belajar, dapat berupa buku, media cetak dan elektronik, alam sekitar, atau sumber belajar lain yang relevan

l. langkah-langkah pembelajaran dilakukan melalui tahapan pendahuluan, inti, dan penutup

m. penilaian hasil pembelajaran.

2) Pelaksanaan

Menurut Syaiful Bahri dan Aswan Zain (2010) pelaksanaan pembelajaran adalah suatu kegiatan yang bernilai edukatif, nilai edukatif mewarnai interaksi yang terjadi antara guru dan siswa. Interaksi bernilai edukatif dikarenakan pelaksanaan pembelajaran yang dilakukan diarahkan untuk mencapai tujuan tertentu yang telah dirumuskan sebelum pelaksanaan pembelajaran dimulai.

Pelaksanaan pembelajaran merupakan implementasi dari RPP, pelaksanaan pembelajaran meliputi kegiatan sebagai berikut:

a. Kegiatan Pendahuluan

1) Menyiapkan peserta didik secara psikis dan fisik untukmengikuti proses pembelajaran.

2) Mengajukan pertanyaan-pertanyaan yang mengaitkan pengetahuan yang sebelumnya dengan materi yang akandipelajari.

3) Menjelaskan tujuan pembelajaran atau kompetensi dasar yang akandicapai.

4) Menyampaikan cakupan materi dan penjelasan uraian kegiatan sesuai silabus (Lampiran Permendikbud, 2016: 9-10).

b. Kegiatan Inti

Kegiatan inti pada kurikulum 2013 proses pembelajaran menggunakanpendekatan scientific, kegiatan ini meliputi;

1) Mengamati, dalam kegiatan ini peserta didik melihat, membaca, mendengar, memperhatikan tayangan dan penjelasan guru tentang materi ajar.

2) Menanya, dalam kegiatan ini peserta didik menanya, member i umpan balik, mengungkapkan sesuatu. Dialog mendalam secara klasikal yang berhubungan dengan materi ajar.

3) Eksplorasi, dalam kegiatan ini peserta didik dikondisikan untuk berpikir kritis, mendialogkan, mengeksperimen dan melakukan diskusikelompok.

4) Mengasosiasi, kegiatan ini peserta didik menghubungkan materi lain dan membuat rumusan dengan melakukan analisis terhadap materipembelajaran.

5) Mengkomunikasi kegiatan ini peserta didik mempresentasikan, mendialogkan, menyimpulkan dari hasil diskusi atau membuat kesimpulan terhadap materi pembelajaran (Nasir A. Baki, 2010: 223-224)

Jadi, kegiatan inti pada kurikulum 2013 menggunakan pendekatan scientific dan pelaksanaan pembelajarannya berpusat pada peserta didik. Tugas guru dalam 
Viviana Fahira, Rengga Satria, dan Ageng Priadi: Pelaksanaan Pembelajaran Pendidikan Agama...

pembelajaran adalah sebagai moderator dan fasilitator yang mengkondisikan peserta didik untuk melakukan kegiatan belajar.

c. KegiatanPenutup

Kegiatan penutup merupakan kegiatan akhir pada proses pembelajaran. Kegiatan ini meliputi:

1) Guru bersama peserta didik membuatkesimpulan.

2) Melakukan penilaian/refleksi terhadap kegiatan yang sudah dilaksanakan secara konsisten danterprogram.

3) Memberikan umpan balik terhadap proses dan hasilpembelajaran.

4) Merencanakan kegiatan tindak lanjut dalam bentuk pembelajaran remedy, program pengayaan, layanan konseling dan atau memberikan tugas individual maupun kelompok sesuai dengan hasil belajar pesertadidik.

5) Menyampaikan rencana pembelajaran pada pertemuan berikutnya (Peraturan Menteri Pendidikan Nasional Republik Indonesia, 2007: 41)

Menurut kurikulum 2013 pelaksanaan pembelajaran PAI di tingkat SMP diajarkan secara komprehensif antara sikap, pengetahuan, dan keterampilan. Pemilihan sumber belajar mengacu pada perumusan yang ada dalam silabus yang dikembangkan. Sumber belajar mencakup sumber rujukan, lingkungan, media, narasumber, alat dan bahan. Sumber belajar dituliskan secara lebih operasional, dan langsung dinyatakan bahan ajar apa yang digunakan (Nasir A. Baki, 2009: 260-261)

3) Evaluasi

Tugas guru setelah melaksanakan pembelajaran adalah melakukan evaluasi hasil pembelajaran. Ngalim purwanto (2010: 3), mengutip pendapat dari Norman E. Gronlund (1976) yang merumuskan pengertian evaluasi adalah sebagai berikut: "Evaluation... a systematic process of determining the extent towhich instructional objectives are achieved by pupils". Evaluasi adalah suatu proses yang sistematis untuk menentukan atau membuat keputusan sampai sejauh mana tujuan-tujuan pengajaran telah dicapai oleh siswa.

Menurut Zainal Arifin (2011:14) tujuan evaluasi pembelajaran adalah untuk mengetahui keefektifan dan efisiensi sistem pembelajaran, baik yang menyangkut tentang tujuan, materi, metode, media, sumberbelajar, lingkungan maupun sistem penelitian itu sendiri.

Dari pendapat-pendapat di atas dapat disimpulkanevaluasi merupakan salah satu komponen penting dan tahap yang harus ditempuh oleh pengajar untuk mengetahui keefektifan suatu proses pembelajaran. Hasil yang didapat dari evaluasi tersebut yang akan digunakan pengajar untuk memperbaiki dan menyempurnakan program dan kegiatan pembelajaran.

\section{Metode}

Jenis penelitian yang digunakan adalah penelitian kualitatif. Penelitian kualitatif adalah jenis penelitian yang digunakan jika masalah yang dihadapi belum jelas, mengetahui makna yang tersembunyi, memahami interaksi sosial, mengembangkan teori, memastikan kebenaran data, serta untuk meneliti sejarah perkembangan (Mamik, 2015: 3).

Sedangkan (Moleong2018: 6), menyatakan bahwa penelitian kualitatif bertujuan untuk melihat dan memahami fenomena apa yang dialami oleh subyek penelitian, seperti perilaku, persepsi, motivasi, tindakan secara holistik, dan dengan cara mendeskripsikannya dengan bentuk kalimat atau kata-kata, pada suatu konteks khusus yang alamiah dan memanfaatkan berbagai metode alamiah.

Jenis penelitian kualitatif yang digunakan pada penelitian ini dimaksudkan untuk memperoleh informasi mengenai pelaksanaan pembelajaran Pendidikan Agama Islam dalam menanamkan nilai-nilai kejujuran di SMP Negeri 2 Kota Solok secara mendalam dan menyeluruh. Jadi peneliti akan mengungkapkan dan mendeskripsikan gejala-gejala yang terjadi dilapangan dengan cara terjun langsung kelapangan dengan melakukan wawancara, observasi dan pengambilan dokumentasi. 


\section{Hasil dan Pembahasan}

\section{a. Perencanaan Pembelajaran PAI dalam Menanamkan Nilai-Nilai Kejujuran Siswa di SMPN2 Kota Solok}

Sebelum melaksanakan proses pembelajaran guru PAI di SMPN2 Kota Solok membuat perencanaan pembelajaran terlebih dahulu, berdasarkan hasil wawancara peneliti dengan kepala sekolah semua guru termasuk guru PAI sebelum mengajar diwajibkan untuk membuat perangkat pembelajaran, hal ini bertujuan agar guru tersebut siap untuk menjalankan tugasnya dalam mengajar serta untuk mencapai sebuah tujuan pembelajaran PAI.

Guru PAI di SMPN 2 Kota Solok sudah membuat perangkat pembelajaran. Hal tersebut ditunjang oleh pihak sekolah yang berupaya membuat program khusus pada setiap awal tahun ajaran baru dengan mengadakan kegiatan Bimbingan Teknis (BIMTEK) untuk menunjang kompetensi guru di bidang pembelajaran termasuk pembuatan perangkat pembelajaran yang di dalamnya terdapat RPP.

Menurut teori yang disampaikan Tjokroamidjojo (Syafalevi,2011: 27) perencanaan merupakan proses mempersiapkan secara sistematis kegiatan-kegiatan yang akan dilakukan untuk mencapai suatu tujuan tertentu. Jadi guru PAI di SMPN2 Kota Solok memang harus mempersiapkan sebuah skenario pembelajaran yang akan dilaksanakan sebelum mengajar.

Sebelum mengajar guru PAI terlebih dahulu membuat RPP yang di mulai dari kegiatan pendahuluan, kegiatan inti dan kegiatan penutup, selain itu sebelum mengajar guru PAI juga menyiapkan media yang diperlukan dan memilih metode yang sesuai dengan materi kejujuran yang akan diajarkan. Guru PAI mulai menanamkan nilai-nilai kejujuran dari tahap pendahuluan dengan memberikan motivasi-motivasi terkait perilaku jujur kepada siswa.

Menurut lampiran permendikbud no 22 tahun 2018, komponen RPP terdiri dari identitas sekolah, identitas mata pelajaran, Kelas/semester, materi pokok, alokasi waktu, tujuan pembelajaran yang dirumuskan berdasarkan KD, kompetensi dasar dan indikator pencapaian kompetensi, materi pembelajaran, metode pembelajaran, media pembelajaran, sumber belajar, langkah-langkah pembelajaran, dan penilaian hasil pembelajaran, berdasarkan kenyataan dilapangan di SMPN2 Kota Solok guru PAI sudah membuat RPP sesuai dengan permendikbud no 22 tahun 2016.

\section{b. Pelaksanaan Pembelajaran PAI dalam Menanamkan Nilai-Nilai Kejujuran Siswa di SMPN2 Kota Solok}

Setelah membuat perencanaan pembelajaran (RPP) tugas guru selanjutnya adalah melaksanakan proses pembelajaran sesuai skenario yang ada dalam RPP. Melaksanakan proses pembelajaran merupakan tugas utama seorang guru pelaksanaan proses pembelajaran akan menjadi lebih baik jika sudah dirancang terlebih dahulu dan pelaksanaan pembelajaran yang baik memang harus sesuai dengan RPP tetapi dalam dalam peristiwayangsering terjadi, terkadang dalam RPP tercantum menggunakan media infocus tapi kenyataannya tidak, hal ini dikarenakan di SMPN 2 Kota Solok media tersebut jumlahnya terbatas, sehingga penggunaan infocus tidak efektif, karena digunakan dengan cara saling meminjam antar guru mata pelajaran lain yang bertepatan pada jam pelajaran yang sama.

Guru PAI melaksanakan pembelajaran PAI dalam menanamkan nilai-nilai kejujuran adalah sebelum pelajaran PAI dimulai siswa berdo'a terlebih dahulu yang di pimpin oleh ketua kelas, setelah itu guru mengecek kehadiran peserta didik dan mencatat berapa sholat wajib yang dikerjakan peserta didik, guru PAI menyuruh mereka berbicara sejujur-jujurnya dan mengatakan tidak ada gunanya peserta didik berbohong karena yang dinilai adalah kejujurannya.

Setelah itu barulah guru memulai pembelajaran, proses pembelajaran berlangsung satu arah yaitu ceramah, guru mengajar sesuai situasi dan kondisi biasanya kalau ada 
Viviana Fahira, Rengga Satria, dan Ageng Priadi: Pelaksanaan Pembelajaran Pendidikan Agama...

media infocus dan keadaan memungkinkan, guru menggunakan media infocus dan menampilkan video, kalau tidak ada dengan metode ceramah saja, dalam penyampaian materi pendidik PAI lebih memberikan motivasi-motivasi kepada siswa terkait perilaku jujur, agar siswa tersebut termotivasi untuk bersikap jujur, setelah itu guru pendidik PAI memberikan tugas individu, guru PAI berusaha untuk mengajak siswa untuk mengerjakan tugas dengan sendiri-sendiri di tempat duduknya masing-masing.

Guru PAI menegaskan tidak perlu bertanya dengan teman kanan kirinya. Jika ada soal yang belum jelas tanyakan langsung kepada guru yang mengajar. Sebelum mengakhiri proses pembelajaran guru PAI memberikan tugas untuk di rumah kepada siswa yaitu hafalan Q.S Al-Baqarah: 42, lalu mengakhiri dengan bacaan salam. Menurut lampiran permendikbud no 22 tahun 2016 pelaksanaan pembelajaran merupakan implementasi dari RPP yang terdiri dari kegiatan pendahuluan, kegiatan inti, dan kegiatan penutup.

Berdasarkan fakta di lapangan pada tahap pelaksanaan pembelajaran, guru PAI di SMPN2 Kota Solok sudah melaksanakan kegiatan sesuai dengan RPP, dan ada juga yang tidak sesuai dengan RPP contohnya pada saat penggunaan media pembelajaran, karna media di SMPN2 Kota Solok terbatas jadi guru PAI mengalihkan pembelajaran dengan menggunakan metode ceramah saja.

\section{c. Evaluasi Pembelajaran PAI dalam Menanamkan Nilai-Nilai Kejujuran Siswa di SMPN2 Kota Solok}

Setelah melaksanakan proses pembelajaran tugas guru selanjutnya adalah melakukan evaluasi pembelajaran, tahap evaluasi dilakukan untuk mengetahui sejauh mana aplikasi sikap peserta didik setelah melakukan pembelajaran di dalam kelas. Melalui evaluasi seorang guru dapat mengetahui implikasi penanaman perilaku jujur kepada peserta didik, cara guru PAI mengevaluasi yaitu melalui pengamatan saat proses pembelajaran, dengan pengamatan selama proses pembelajaran, guru PAI memiliki penilaian sendiri dan menandai anak yang berbuat tidak jujur tersebut lalu mengisi di instrumen penilaian, jika ada siswa yang terbukti tidak jujur guru akan menandainya.

Ngalim purwanto (2010: 3), mengutip pendapat dari Norman E. Gronlund evaluasi adalah proses yang sistematis untuk menentukan atau membuat keputusan sampai sejauh mana tujuan-tujuan pengajaran telah dicapai oleh siswa.

Berdasarkan wawancara dengan kepala sekolah cara mengevaluasi peserta didik yang bersikap tidak jujur dalam proses pembelajaran PAI yaitu harus dibina dulu oleh guru agama, selanjutnya jika masih belum ada perubahan maka akan dilaporkan ke wali kelas, pembina osis dan bagian kesiswaan.

Pada Tahap ini orang tua akan dipanggil untuk dicari solusi terbaik dan seandainya tidak ada perubahan maka akan dirapatkan oleh dewan guru dan kepala sekolah saat rapat penentuan kenaikan kelas dengan sanksi tidak bisa naik kelas, karena jika dari masa remaja saja sudah tidak jujur ditakutkan ketika dewasa akan melahirkan koruptor hebat, makanya sikap tidak jujur ini harus ditindaklanjuti dengan tegas.

Berdasarkan hasil evaluasi bahwa secara umum peserta didik mempunyai akhlak yang baik, terutama tentang sikap jujur, namun ternyata masih terdapat juga beberapa peserta didik yang bersikap tidak jujur. Hal ini dapat diamati pada saat jam PAI masih ada beberapa siswa yang tidak jujur dan masih berusaha untuk mencontek.

d. Faktor Penghambat dan Pendukung Pelaksanaan Pembelajaran PAI dalam Menanamkan Nilai-Nilai Kejujuran di SMPN2 Kota Solok

a. Faktor pendukung

1) Implementasi Kurikulum 2013

Hasil pemangatan peneliti, SMP Negeri 2 kota Solok menggunakan kurikulum 2013, dengan adanya implementasi kurikulum 2013 sangat mendukung proses pelaksanaan pembelajaran PAI dalam menanamkan nilai-nilai kejujuran di SMP Negeri 2 kota Solok karna Semua guru termasuk guru agama Islam mempunyai 
tugas untuk membina sikap peserta didik, didalam kurikulum 2013 ini ada tiga aspek yaitu sikap, pengetahuan, dan keterampilan. Dari ketiga aspek penilaian tersebut, aspek terpenting adalah sikap karena kurikulum 2013 sangat mengedepankan penilaian sikap, baik sikap spiritual maupun sikap sosial untuk semua mata pelajaran.

2) Faktor Usia Peserta Didik

Faktor usia peserta didik juga menjadi salah satu faktor pendukung pelaksanaan pembelajaran PAI dalam menanamkan nilai-nilai kejujuran, karena peserta didik kelas VII ini merupakan peralihan dari SD ke SMP, umur mereka kisaran 12-13 tahun dan mereka masih tergolong polos, sikap mereka yang polos tersebut membuat mereka mau mendengarkan apa yang disampaikan guru tanpa harus membantah. Jadi guru juga lebih mudah menanamkan nilai-nilai kejujuran kepada mereka.

3) Kegiatan Ekstra Pengajian Siswa

Kegiatan ekstra pengajian siswa merupakan faktor penting dalam pelaksanaan pembelajaran PAI dalam menanamkan nilai-nilai kejujuran, karena di SMPN 2 Kota Solok adalah sekolah umum yang mata pelajaran agamanya hanya satu kali pertemuan jam pelajaran dalam seminggu. Hal tersebut dirasa kurang memadai dalam mengajarkan ajaran-ajaran Islam secara mendalam kepada siswa, Jadi perlu kegiatan ekstra untuk menambah wawasan keagamaan siswa agar dapat lebih memahami ajaran islam, Pada kegiatan ini siswa diajarkan untuk lebih memahami ajaran islam, contohnya berakhlak baik yaitu sikap jujur dan sikap disiplin serta kegiatan membaca Al-Qur'an.

b. Faktor penghambat

1) Fasilitas yang kurang memadai

Fasilitas yang kurang memadai merupakan faktor penghambat bagi proses pembelajaran PAI dalam menanamkan nilai-nilai kejujuran di SMPN2 Kota Solok, berdasarkan hasil observasi peneliti di SMPN 2 Kota Solok fasilitas berupa infocus jumlahnya terbatas, media infocus yang terbatas membuat pelaksanaan pembelajaran menjadi tidak efektif karena digunakan dengan cara saling meminjam antar guru mata pelajaran lain yang bertepatan pada jam pelajaran yang sama.

2) Kurangnya keamanan di sekolah

Masalah keamanan di SMPN 2 Kota Solok sebenarnya sudah terbilang aman, akan tetapi karena lingkungan halaman yang terlalu luas dan kondisi pagar yang belum terselesaikan dengan baik, membuat siswalebih mudah untuk bolos sekolah, mereka memanfaatkan kondisi yang ada pada lingkungan, karena kondisi pagar yang tidak maksimal dan terbilang pendek maka siswa memanfaatkan untuk kabur dan bolos, dengan alasan mereka izin ke wc padahal sebenarnya mereka bolos.

e. Hasil Proses Pelaksanaan Pembelajaran Pendidikan Agama Islam dalam Menanamkan Nilai-Nilai Kejujuran di SMPN 2 Kota Solok

Pelaksanaan pembelajaran Pendidikan Agama Islam sudah mengarahkan tentang penanaman sikap jujur. Dalam proses pembelajaran PAI guru mengajarkan peserta didik untuk berprilaku jujur namun masih ada sebagian peserta didik yang tidak jujur.

Berdasarkan hasil pelaksanaan pembelajaran PendidikanAgama Islam di SMPN 2 Kota Solok bahwa tugas guru terkait perencanaan sudah baik, namun saat proses pelaksanaan pembelajaran masih terdapat kekurangan, berupa media infocus yang tidak lengkap, Selanjutnya guru melakukan proses evaluasi pembelajaran. Berdasarkan hasil pengamatan bahwa sebelum mengajar, guru membuat perencanaan pembelajaran atau RPP.

Dalam pelaksanaan pembelajaran sebagian guru terkadang mengajar sesuai RPP namun terkadang tidak sesuai RPP. Untuk mengantisipasi hal tersebut, mayoritas 
Viviana Fahira, Rengga Satria, dan Ageng Priadi: Pelaksanaan Pembelajaran Pendidikan Agama...

guru mengajar dengan mengalihkan melalui metode ceramah, sehingga terkesan kurang efektif dan kurang menarik.

Berdasarkan hasil evaluasi bahwa secara umum peserta didik mempunyai akhlak yang baik, terutama tentang sikap jujur, Namun ternyata masih terdapat juga peserta didik yang bersikap tidak jujur. Hal ini dapat diamati pada jam PAI maupun di luar jam PAI masih banyaknya siswa yang tidak jujur.

Berdasarkan hasil pelaksanaan pembelajaran PendidikanAgama Islam di SMPN 2 Kota Solok bahwa tugas guru terkait perencanaan sudah baik, namun saat proses pelaksanaan pembelajaran masih terdapat kekurangan, tidak semua guru mengajar sesuai perencanaan atau RPP. Selanjutnya guru melakukan proses evaluasi pembelajaran. Guru mengevaluasi dengan melakukan penilaian sendiri, guru mengamati sikap jujur siswa pada saat proses pembelajaran lalu mengisi lembar penilaian, dan berdasarkan hasil pengamatan bahwa sebelum mengajar, guru membuat perencanaan pembelajaran atau RPP.

Dalam pelaksanaan pembelajaran sebagian guru terkadang mengajar sesuai RPP namun terkadang tidak sesuai RPP. Untuk mengantisipasi hal tersebut, mayoritas guru mengajar dengan mengalihkan melalui metode ceramah, sehingga terkesan kurang efektif dan kurang menarik.

Berdasarkan hasil evaluasi bahwa secara umum peserta didik mempunyai akhlak yang baik, terutama tentang sikap jujur . Namun ternyata masih terdapat juga peserta didik yang kurang berakhlak baik. Hal ini dapat diamati di dalam jam PAI maupun di luar jam PAI.

Hasil pengamatan peneliti, sikap jujur peserta didik dapat diamati saat proses pembelajaran PAI maupun diluar jam pelajaran PAI, ketika proses pembelajaran PAI guru memperhatikan bagaimana cara siswa bersikap, dapat diamati para peserta didik sudah mampu untuk mandiri mengerjakan soal-soal yang diberikan guru tanpa mencontek satu sama lain, mereka juga bersedia mengakui kesalahan jika terbukti bersalah, mereka juga mau menegur jika ada teman yang mencontek, dan alhamdulillah sekarang mereka sudah tidak membolos lagi, biasanya kebanyakan dari mereka izin ke wc malah nongkrong dinkantin dan bahkan ada yang membolos.

\section{Simpulan}

Guru PAI mempunyai peran yang penting untuk menanamkan nilai-nilai kejujuran pada peserta didik dalam proses pembelajaran. Sebelum mengajar guru PAI membuat perencanaan berupa RPP, dan dalam pelaksanaan pembelajaran guru menjadi teladan bagi peserta didik, guru senantiasa menanamkan sikap jujur dalam pembelajaran. Setelah itu, guru melakukan evaluasi dengan mengamati secara langsung akhlak peserta didik untuk mengetahui sejauh mana aplikasi pelaksanaan pembelajaran PAI dalam menanamkan nilainilai kejujuran peserta didik di SMPN 2 Kota solok.

Faktor Pendukung:

1) Implementasi kurikulum 2013 yang dilakukan dengan cara kerjasama oleh semua guru bidang studi karena pada semua mata pelajaran mengharuskan melakukan penilaiansikap.

2) Faktor Usia Peserta Didik

faktor usia peserta didik juga salah satu faktor pendukungnya, karena peserta didik kelas VII ini merupakan peralihan dari SD ke SMP, umur mereka kisaran 12-13 tahun dan mereka masih tergolong polos, sikap mereka yang polos tersebut membuat mereka mau mendengarkan apa yang disampaikan guru tanpa harus membantah. Jadi guru juga lebih mudah menanamkan nilai-nilai kejujuran kepada mereka.

3) Kegiatan Ekstra Pengajian Siswa

kegiatan yang menjadi pendukung penanaman akhlak baik seperti kejujuran peserta didik di sekolah yaitu adanya pengajian siswa sebagai kegiatan tambahan bagi 
peserta didik yang beragama Islam. Kegiatan ini bersifat ekstra untuk menambah wawasan keagamaan dan sebagai ajang pembinaan akhlak pesertadidik.

Faktor Penghambat

1) Fasilitas yang kurang memadai

Hasil observasi peneliti di SMPN 2 Kota Solok adalah, fasilitas berupa infocus jumlahnya terbatas, media infocus yang terbatas membuat pelaksanaan pembelajaran tidak efektif.

2) Kurangnya keamanan di sekolah Masalah keamanan di SMPN 2 Kota Solok sebenarnya sudah terbilang aman, akan tetapi karena lingkungan halaman yang terlalu luas dan kondisi pagar yang belum terselesaikan dengan baik membuat siswa lebih mudah membolos.

Hasil proses pelaksanaan pembelajaran PAI dalam menananmkan nilai-nilai kejujuran di SMPN2 Kota Solok bapai belum tercapai secara maksimal, Guru PAI sudah membuat perencanaan pembelajaran namun kenyataannya pada saat pelaksanaan pembelajaran tidak sesuai harapan sebagaimana dengan RPP, karena berbagai hambatan. Sebagian peserta didik sudah berprilaku jujur, namun masih ada beberapa yang tidak bersikap jujur karena faktor lingkungan tempat tinggal dan keluarga.

\section{Referensi}

Abdul Majid dan Dina Andayani, Pendidikan Agama Islam Berbasis Kompetensi, (Bandung: Remaja Rosdakarya,2010), h. 132

Abdul Majid, Perencanaan Pembelajaran: Mengembangkan Standar Kompetensi Guru (Cet.IX; Bandung: PT. Remaja Rosdakarya, 2012), h. 15.

Agus Wibowo, Pendidikan Karakter: Strategi Membangun karakter Bangsa Berperadaban, Yogyakarta, Pustaka Pelajar, 2012, hal.14 9 Nurul Zuriah, Pendidikan

Agus Wibowo, Pendidikan Karakter: Strategi Membangun karakter Bangsa Berperadaban, Yogyakarta, Pustaka Pelajar, 2012, hal.14

Ahmad D. Marimba, Pengantar Filsafat Pendidikan Islam, (Bandung: Al-Ma'arif, cet VII,2007),h. 47

Amin, M. (2017). Peran Guru Dalam Menanamkan Nilai Kejujuran Pada Lembaga Pendidikan. TADBIR: Jurnal Studi Manajemen Pendidikan,1(1), 105-124. Error! Hyperlink reference not valid..

Cholil Umam, Ikhtisar Ilmu Pendidikan Islam, (Surabaya: Duta Aksara,2008),

Darmiyati Zuchdi, Pendidikan Karakter: Teori dan Praktik Yogyakarta, UNY Press, 2011, hal.251-252

Daryanto, Evaluasi Pendidikan, (Jakarta: Penerbit Rineka Cipta, 2008), Hlm: 11

https:// Daryanto Evaluasi Pendidikan, Jakarta Penerbit Rineka Cipta

Depag RI. Al-Qur'an dan Terjemahannya, (Semarang: karya Toha Putra, 2005)

Djamarah, Syaiful Bahri dan Aswan Zain. 2010. Strategi Belajar Mengajar. Jakarta: Rineka Cipta

Fandi Setiawan, "Kemampuan Guru Melakukan Penilaian dalam Pembelajaran Melalui Internalisasi Nilai Kejujuran pada Pembelajaran Pendidikan Kewarganegaraan," Jupiis Vol. 5 No. 2 (Desember 2013): h. 75. Error! Hyperlink reference not valid.

Indah Komsiyah, Belajar Dan Pembelajaran, (Yogyakarta: Penerbit Teras, 2012), hal:110 https://Indah Komsiyah Belajar Dan Pembelajaran Yogyakarta Teras 2

Jai, A. J., Rochman, C., \& Nurmila, N. (2019). Peran Pendidikan Agama Islam Dalam Membentuk Karakter Jujur Pada Siswa. Al-Tadzkiyyah: Jurnal Pendidikan Islam, 10(2), 257-264.

Kemendikbud, Pengantar Umum Silabus PAI kurikulum 2013. (Jakarta 2012)

Majid, "Belajar dan pembelajaran"( 2010 op.cit., 15-16.) Mamik. (2015). Metodologi Kualitatif. Sidoarjo: Zifatama Jawara.

Moleong, L. J. (2018). Metodologi Penelitian Kualitatif Edisi Revisi. Bandung: PT Remaja Rosdakarya. 
Viviana Fahira, Rengga Satria, dan Ageng Priadi: Pelaksanaan Pembelajaran Pendidikan Agama...

Moral dan Budi Pekerti dalam Perspektif Perubahan: Menggagas Platform Pendidikan Budi Pekerti Secara Kontekstual dan Futuristik, Jakarta, Bumi Aksara, 2007, hal.83

Muhaimin, Peradigma Pendidikan Islam: Upaya Mengefektifkan PAI di Sekolah, (Bandung: RemajaRosdakarya, 2008), h. 145

Nurul Zuriah, Pendidikan Moral dan Budi Pekerti dalam Perspektif Perubahan: Menggagas Platform Pendidikan Budi Pekerti Secara Kontekstual dan Futuristik, Jakarta, Bumi Aksara, 2007, hal.83

Oemar Hamalik, Kurikulum Dan Pembelajaran, (Jakarta: Bumi Aksara, 2007)

Rofiq, M. N. (2010). Pembelajaran kooperatif (cooperative learning) dalam pengajaran pendidikan agama Islam. Jurnal Falasifa, 1(1), 1-14.

Samsul Munir Amin, Ilmu Akhlak (Jakarta: Amzah, 2016), h. 205.

Samsul Munir Amin, Ilmu Akhlak (Jakarta: Amzah, 2016), h. 205.

Shafwat Abdul Fattah M., Jujur Menuju Jalan Yang Benar, Bintang Cemerlang, (Jogjakarta: 2001) hlm 61

Sugiyono. (2008). Metode Penelitian Kuantitatif Kualitatif dan R\&D. Bandung: Alfabeta.

UMMAH, K. (2017). Pelaksanaan Pembelajaran Pendidikan Agama Islam (PAI) Kelas XII pada Lembaga Pendidikan Nonformal Program Kejar Paket C di PKBM Rasio Kota Blitar Tahun Pelajaran 2016-2017 (Doctoral dissertation) Error! Hyperlink reference not valid.

Wibowo, W. (2011). Cara Cerdas Menulis. Jakarta: Penerbit Buku Kompas. Error! Hyperlink reference not valid.

Zuhairimi, Metodik Khusus Pendidikan Agama, (Surabaya: Usaha Offset Printing, 2007), h. 25 